\title{
Tahqqiqul Manāth in Madzhab-Contextualization of Non-Muslim Status in Indonesia
}

\section{Muhammad Faeshol ${ }^{*}$ and Akhmad Khisni**)}

*) The Central Java PWNU Bahtsul Masail Institute, Lecturer at Pondok (Islamic Boarding School) Kulon Banon Kajen, PP. Al-Asas Mubtadi'in Kajen and Ma'had AlyMaslakul Huda Kajen.

**) Lecturer of Master of Law, Faculty of Law, Universitas Islam Sultan Agung Semarang

\begin{abstract}
.
The fatwa or decision of Bahtsul Masail which gave the status of non-Muslim Indonesians given the status of harbi fi dzimmati tta'min was corrected by the Nahdlatul Ulama National Conference in Banjar City, West Java in 2019. Using a legal contextuality within the framework of the Imam Syafi'i school of thought, Nahdlatul Ulama 'stated Indonesian nonMuslims as non-Muslims are ordinary citizens who are the same as Muslim citizens and are not included in one of the four categories of kafirs in the schools with all the legal consequences. Contextualization as an effort to understand a law according to its context is carried out so that the law of fiqh madzhab in its application adapts to the changing and different context of reality. Ignorance of changes and differences in context will result in the application of the law of fiqh madzhab which violates the school itself.mahall al-hukmi and ahl al-hukmi. The results of the National Conference as a correction to the different previous fatwas were carried out as a necessity so that the application of the law of fiqh madzhab was correct in its application. Not to change the law of the school of fiqh. The four categories of kafir remain in the madzhab as a kulli concept. But implementing it must be appropriatemahall al-hukmi her.And non-Muslims in Indonesia are not mahall al-hukmi is right for the concept.

Keywords: Tahqiquul-Manāț; Madzhab-Contextualization; Status of Non-Muslims; Nahdlatul Ulama National Conference.
\end{abstract}

\section{Introduction}

At the end of February 2019 Jam'iyyah Nahdlatul Ulama held a National Alim Ulama Conference in Banjar Patroman, West Java. One of the decisions of the National Conference has caused controversy and misunderstanding, including the kiai in the body of Jam'iyyah Nahdlatul Ulama. The decision is that a decision regarding non-Muslim status in Indonesia according to Fiqh Law cannot be included in one of the four categories of kafir; dzimmi, musta'man, mu'āhad and harbi as known in Imam Syafii's fiqh books, which have become references to many Islamic boarding schools in Indonesia as well as Jam'iyyah Nahdlatul Ulama.

The decision of the NU National Conference can also be interpreted as a correction to several decisions of the Bahtsul Masail forum that had been held by previous Islamic boarding schools. For example, the decision of the Bahtsul Masail Forum for Islamic Boarding School Deliberation (FMPP)3rd on-Residency Kediri, at Ma'had Al Falah Trenceng Sumbergempol, Tulungagung on 29-30 September 
1998. ${ }^{1}$ At that time, Bahtsul Masail raised a question that was discussed was about the status of non-Muslims in Indonesia and the extent of protection given to them by Islam. Given that if the status is kafir harbi, the property of non-Muslims will not receive protection. Meanwhile, if the status is kafir dzimmi, of course there is an obligation to pay jizyah. With reference tofatwa of Shaykh Ismail Zain Al-Yamani (d. 1414 H), mufti of the Shafi'i Madzhab who lives in Makkah, the following answers were decided: "Because between non-Muslim citizens and imams there is no contract that is justified (in accordance) with the customs stated in the book, then the status of non-Muslims in Indonesia according to the qoul chosen by the musyawirin is included as kafir harbi fii dzimmatit ta'min (kafir harbi who gets protection). Islamic protection for non-Muslim citizens in Indonesia includes protection for their lives and assets. Because the fasid contract in the matter of protection is a shohih contract." 2

In line with this decision, FMPP XIV throughout Java and Madura in PP. Mifathul Ulum Al-Yasini, Areng-areng Pasuruan, East Java, on 23-24 February 2006. The decision departed from the question of suicide bombings carried out by terrorist groups on the grounds of jihad, as follows:

"In the context of jihad, it is not justified. Because infidels in Indonesia are included in the category of kafir harbi fi dzimmah al-ta'min min al-imam (kafir harbi who receive a guarantee of safety from the imam) which the government cannot kill, harass (ightiyal), and others, as well as because they will cause a greater impact of mafsadah than the maslahah to be achieved. "3

In contrast to Bahtsul Masail's decision, the National Conference of NU prefers to use the term muwaāthin or citizens who do not include dzimmi, musta'man, mu'ähad and harbi. ${ }^{4}$ The difference in fatwas or decisions taken by the NU National Conference does not mean that they violate the law of fiqh in the schools of thought. But the differences in the application of fiqh law within the schools of thought. The application of this law is the result of the contextualization of fiqh law in the school of thought.

The contextualization that is the object here is the law of fiqh which is the school of thought, not a verse of the Quran or hadith. The contextualization in question is an attempt to understand the context of a fiqh law in the school of

\footnotetext{
${ }^{1}$ Muhammad Faeshol was present as a participant to become a delegation of PP delegates. MUS Sarang Rembang.

2 Kthe decision of Bahtsul Masail FMPP III As the residency of Kediri, http://www.gubuklentera.com/2016/11/status-non-muslim-di-indonesia.html. Accessed on 14 February 2020, 21.00 WIB.

3 The decision of Bahtsul Masail FMPP XIV in Java and Madura in PP. Mifathul Ulum Al-Yasini, Areng-areng Pasuruan, http://www.gubuklentera.com/2016/11/konsep-jihad-dan-amar-marufnahi-munkar.html?m=1. Accessed on 14 February 2020, 21.10 WIB.

${ }^{4}$ See the 2019 Nahdlatul Ulama Alim Ulama National Conference Material, the Bahtsul Masail AdDiniyyah Al-Maudluiyyah Commission. In the discussion material as a draft of the National Conference results, contextualization is mentioned as an approach in formulating decisions on the theme "State, Citizenship and State Law." Meanwhile, the official results of the National Conference have not been published until this article was written. The author was present as a participant and delegation of the Central Java PWNU delegation. Previously, the author participated in formulating this method in the Bahtsul Masail Pra Munas held at PP. Al-Hasaniyah Rawalini Teluknaga, Tangerang, West Java 15-16 February 2019.
} 
thought so that the suitability of the law can be found in the context of the problem being discussed. If it is not appropriate, then the law of fiqh cannot be enforced and another law must be stipulated. If forced, the fiqh law will violate the school itself. KH. Sahal Mahfudh (Rais Amm PBNU 1999-2014), emphasized the importance of following the school of thought by paying attention to the context in its application. This means that the law of fiqh is presented not just a copy-paste of the ulama's answers in the past without seeing the context that has changed. ${ }^{5}$

Regarding the contextualization of the status of non-Muslims in Indonesia, KH. Sahal Mahfudh, first said in 2010:

"If there is a fiqh product that does not lead to the creation of justice in society, it must be abandoned. For example, political jurisprudence (fiqih siyasah), which often has dictums not in line with the idea of democracy which requires justice and equality of human rights before the law. The formulation of classical siyasa fiqh usually places the kafir group as "second class", not an equal entity with Muslims. I think this view should begin to change. Because this view is not only conflicting with the idea of modern democracy but also against the idea of a nation-state like Indonesia professionalism, abilities and capabilities should be the first choice, not Muslim or not, not men or women. " 6

Meanwhile, contextualization is a foreign term that needs to be referred to in Islamic science, in this case Ushul Fiqih as a science of istinbāt law. And among the istinbāt method known in Ushul Fiqih is Tahqīqul Manāt. Tahquiqul Manāt according to Imam Tajuddin Al-Subki is a study to find the illat of law (which has been found by imam mujtahid) in far'u (maqīs), namely the problem (wāqi'ah) being discussed. ${ }^{7}$

So, based on the above background, this research is aimed; first, to know Tahqiquul Manāt as a method of contextualizing the school of thought and second, to find out how the application and results of Tahqiqul Manāt on the status of nonMuslims in Indonesia

\section{Research Methods}

To achieve the two objectives above, this research was conducted using normative legal research with literature sources in the form of fiqh, Ushul Fiqih, tafsir, the history of the Prophet and articles in scientific journals as well as several additional sources of documents stored in trusted cyberspace sites. This research is a descriptive type of analysis, using the istinbath research approach of the Islamic school of fiqh law in a manhaji manner.

\section{Result and Discussion}

\subsection{Taḥqiqul Manāț as a Method of School contextualization}

\footnotetext{
5 Sahal Mahfudh, Foreword Ahkamul Fuqaha; Solutions to the Problems of Actual Islamic Law; Decisions of the Congress, National Conference, and Congress of the Nahdlatul Ulama (1926-2004), Khalista and LTNU East Java.

${ }^{6}$ Ibid.

7 Tajuddin Al-Subki, Jam'ul Jawami ', Darul Ilmi, Surabaya, juz. 2, p. 292.
} 
In Ushul Fiqih there are terms similar to Tahqiqqul Manāt, namely Takhriijul manath and Tanqīhul Manāt. Takhrijul manath and Tanqīhul Manāt are two types of research on the text of the argument that the mujtahid priests did to find the illat of a law as part of istinbaathul ahkaam. Both are in the area of the imam mujtahid. Meanwhile Tahqiqqul Manāt is more of a research work by the followers of the madzhab on new problems as an application of the findings of the illat that have been carried out by Imam mujtahid. Tahqiqul Manāt is a study to find the illat of law (which has been found by the imam mujtahid) in far'u (maqiss), namely the problem (wāqi'ah) being discussed. ${ }^{8}$

Imam Ghazali explained the operation of Tahqiqqul Manāt by proving the truth in muqaddimah juz'iyyah (muqaddimah șughro) in legal istintāj. In the two statements "every drink that is intoxicating is haram" and "drink A is considered intoxicating", the first is muqaddimah kulliyyah (muqaddimah kubro) and the second is muqaddimah juziyyah. Proof that drinking is intoxicating law meanwhile, to prove the truth of muqaddimah juziyyah requires knowledge of the reality of mahkūm 'alaih. That is ijtihad using Tahqiqul Manāt. ${ }^{9}$

So, in Tahqīqul Manāt - as emphasized by Imam Al-Syathibi, the main condition is knowledge of the issues being discussed (wäqi'ah) in full and detail. This knowledge is not knowledge of fiqh law but knowledge or tashowwur of mahkūm 'alaih. This knowledge is obtained by referring to experts in the field (ahlu khibrah or ahlul ma'rifat). ${ }^{10}$

Imam Ghazali in the Principle of Al-Qiyas stated that Tahqìqul Manāt was used to know the nature of many concepts of knowledge. Among them are 5 (five) concepts of knowledge (nadhariyyah) related to fiqh law, namely (1) lughawiyah (language), (2) urfiyyah (customs), (3) aqliyyah (law of reason), (4) hissiyyah (sensory knowledge) and (5) thabii'iyyah (physical reality). And the results of a study of a different mahkūm 'alaih will make law changes. Due to its breadth and importance, Imam Ghazali asserted that 90 percent of the jurisprudence lies determined by this Tahqiqqul Manāt. ${ }^{11}$

Tahqìqul Manātnot only to prove the existence of illat a sharia law in reality, but also the existence of "illat-illat" which becomes a condition for the application of a sharia law in reality. Imam Ghazali explained that the cultivation of a law is not only determined by the illat of the law, but also by the existence of conditions, the existence of mahall al-hukmi, and the existence of ahl lil-hukmi. All these elements are also called "illat" in the sense that the concept of illat is borrowed from illat in logic ('aqli). In the science of logic, illat is defined as "al-müjib lil-hukm" (things that can cause a law to exist). If one element does not exist then the law does not exist either. In this it is the same; if one of the illat laws, conditions, mahall al-hukmi

\footnotetext{
8 Tajuddin Al-Subki, Loc. Cit.

${ }^{9}$ Al-Ghazali, Muhammad bin Muhammad. (2012). Al-muștașfa min 'ilm al-uṣul. Damascus: Muassasah Arrisalah. juz 1, p. 285.

${ }^{10} \mathrm{Al}$-Syathibi, Ibrahim bin Musa Al-Andalusi. (2004). Al-Muwafaqat. Beirut: Darul Kutub AlIlmiyyah. juz 5, p. 128.

${ }^{11}$ Al-Ghazali, Muhammad bin Muhammad. (1993). Asas Al-Qiyas. Riyadl-Saudi Arabia: Maktabah AlUbaikan. p. 42.
} 
(legal object), or ahl lil-hukmi (legal subject) does not exist ${ }^{12}$ The law of fiqh as a concept still exists but it cannot be applied if the reality does not match.

The jurisprudence law contained in the madzhab books is a set of concepts (kulli). If it has been revealed in a case it is called a fatwa or tanzil al-hukm or taţbìq al-hukm. The fiqh law will be different again if it has been changed to a judge's decision. The decision of a judge apart from being based on the laws of fiqh, in his decision he must look at legal facts by listening to witnesses and looking at the evidence. The law of fiqh in the hands of judges is binding because it has become an instrument of the state in resolving disputes between citizens. Unlike the fatwa which is not binding.

In the application of the law of fiqh it is strongly influenced by the results of the analysis of mahkūm 'alaih. A mufti must observe makūm 'alaih carefully with all the surrounding realities, namely illat, conditions, illat law, conditions, mahall al-hukmi, and ahl lil-hukmi. Errors in observing legal facts will cause the law to be applied to be incorrect. Laws applied by a mufti and even a mujtahid that are based on misunderstanding reality should not be followed.

Correction of a fatwa that is wrong due to an error in paying attention to reality must be made. Correction by using Tahqiqqul Manāt, for example, was carried out by Shaykh Muhammad Mukhtar bin 'Atharid Al-Jawi (d. 1930) in his treatise, Al-Shawaa'iq al-muhriqah lil-awhaam al-kaadzibah fii bayaani hillil Belut warraddi 'alaa man harramah (Burning Lightning Assumption- Assumption of Lies; Explanation of the Halalness of Eels and Answering Those Who Prohibit It). In the Seventh Point [p. 7-8], this Javanese scholar who teaches at the Haram Mosque refutes the assumption of some people that eels are animals that live in two realms by what he calls tahqiiq or proof. Namely, proof that eels are aquatic animals; not an animal that lives in two realms. This research he did with Musyāhadahor see first-hand the life of an eel in detail. The research was carried out in five ways; a place to live, a place to sleep, a place to find food, the inability to live for a long time outside of water and the absence of eels in dry land. This is including the Tahqiiqul Manaath of sense objects

The jurisprudence law that kulli as a result of istinbāt mujtahid and all istinbāt principles is called the Madzhab. KH. Dr. Ahmad Nahrawi Abdussalam defined schools as:

"The unity between the opinions of the mujtahid in the laws of the Shari'a is extracted from the detailed arguments of the Shari'a and the principles and ushul that form the basis of these laws, which are interrelated with one another. So the Shafi'i school means covering Ushul Fiqih and fiqh of Imam Shafi'i radliyallahu 'anhu. "13

And the kulli fiqh which became the school, Imam Qarafi mentioned there were only five elements. These five schools must be followed by followers (muqallid). First, the laws of furu'iyyah which are ijtihadiyyah such as the prayer qunut is sunnah according to Imam Shafi'i. Second, it is the causes of a law such as

\footnotetext{
${ }^{12}$ Al-Ghazali, Muhammad bin Muhammad. (2012). Al-muștașfa min 'ilm al-ușul. Damascus: Muassasah Arrisalah. juz 1, p. 361. Al-Ghazali, Muhammad bin Muhammad. (1971). Syifaaul-Ghalil, Al-Ershad, Baghdad, p. 490-491.

${ }^{13}$ Ahmad Nahrawi Abdussalam. (1988). Al-imām al-shafi'i fi madzhabaihi al-qadīm wal jadīd. p. 207.
} 
the five times breastfeeding which is the cause of the arising of the mahram status. Third, the requirements of a law such as the existence of two witnesses as a legal condition for a marriage. Fourth, the barrier (maani') of a law such as the presence of unclean clothes on the clothes hinders the permissibility of praying by wearing them. Fifth, the provisions of evidence in court, such as not accepting children from witnessing in proof of murder. ${ }^{14}$

Apart from these five things, it is not included in the law of fiqh as a madzhab, which consequently must be followed by followers of the madzhab. AlQarāfi gave an example with an opinion of Imam Malik. Imam Malik argued that the contract of buying and selling and leasing land in the land of Egypt was illegal because according to Imam Malik the land of Egypt was conquered by war. Observing the jurisprudence law above, Imam Qarafi made a distinction which is the law of fiqh which is the madzab and which law of fiqh is derived from the school of thought In that statement, what became the school of thought was a statement that the contract of sale and purchase and lease of land from a country conquered by war was illegal. This is fiqh furu'iyyah ijtihadiyyah. Meanwhile, the statement that the country of Egypt was conquered by war is the result of shahada, not from istinbat. And therefore it does not have to be followed because it is not part of the school. As a result of the Imam Madzhab's syahadah (especially those under it), the muqallid can review its truth according to historical facts.

According to the author, this review includes Tahqiqul Manāt in historical nadhariyyah. The application of the law "sale and purchase agreement and lease of land from a country conquered by war" against an area must be preceded by the historical Tahqiqqul Manāt of that area. Tahqiqqul Manāt is carried out so that the application of the law becomes correct. The results of Tahqiqul Manāt must still be applied even though they differ from the opinion of the law-originating school of thought. If a law on a mahkūm 'alaih which in its determination bases its tașawwur on historical data, it must be corrected and changed, if new, more valid historical data is found. If it does not change, it will violate the school itself.

The idea of contextualizing Islamic law is a view that understands the ideals of law and the reality of effort. The contextual offer of fiqh is an effort to dialogue religious texts with the dimensions of reality. ${ }^{15}$ In the framework of the school of thought, contextual means the effort to place the kulli fiqh law which becomes the madzhab according to its reality. So that the application (factoring) of the law of fiqh to a reality is in accordance with the reality that the jurisprudence law should exist. Reality that changes or is different requires a change in the law of fiqh itself.

\subsection{Taḥqiqul Manāț Non-Muslim Status in Indonesia}

Bahtsul Masail's decision to grant non-Muslim status in Indonesia as harbi fi dzimmati al-ta'min based on the fatwa of Shaykh Ismail Zain Al-Yamani(d. $1414 \mathrm{H}$ ), mufti of the Shafi'i Madzhab who lives in Makkah in his fatwa collection, Qurratul 'Ain. Following are the editors of the fatwa:

\footnotetext{
${ }^{14}$ Al-Qarāfi Al-Maliki. (2009). Al-ihkaam fii tamyiiz al-fataawaa 'an al-ahkaam wa tasharru Benefits al-Qadli wal-imaam, Dār al-Basyāir al-Islamiyyah. Beirut: Cet. IV. p. 191-200.

15 Sanusi. (2015). "Merajut Nalar Fiqih Kontekstual”. STAIN Kudus: Yudisia, Vol. 6, No. 2. p. 471.
} 
"Alhamdulillah, your country has become independent, but there are ceaselessly many infidels, even though the majority of the country's population is Muslim. But the government treats the entire population, both Muslim and infidel, and you say that in fact the conditions of the dzimmah that are mu'tabar are mostly not fulfilled on the part of the kafirs. Are they considered dzimmi or harbi kafir, and are we allowed to disturb them by hurting them openly... Until the end of the question?"

I (Shaykh Ismail Zain) replied: Know that the infidels who are in your country and other countries in Muslim areas such as Pakistan, India, Syria, Iraq, Sudan, Morocco and others, are not dzimmi, mu'ahad or musta'man kafirs, even they are a purely arbi kafir group ... but to be openly hostile to them, as you call it in the question it is necessary to look at the rules of "attracting benefit and rejecting damage", and "what is superior is to resist damage rather than attract benefit", especially for human individuals where they do not have the ability to act like that as the reality exists and is seen. ${ }^{16}$

Meanwhile, the 2019 Nahdlatul Ulama Alim Ulama National Conference saw that this concept was born from and for areas that were included in Darul Islam by means of military conquest or war. The concept of the four categories of kafir is determined based on the contract or the absence of a contract.

Kafir dzimmi in the term fiqh of non-Muslim citizens in areas that have been conquered by the Islamic government who then carry out 'aqd al-dzimmah, namely agreements, contracts or agreements on protection guarantees. 'aqd al-dzimmah can be valid forever, indefinitely. Based on this agreement, they are guaranteed protection of life, property and honor from the Darul Islam government and all Muslims while they are in the Darul Islam area. Including protection from aggression from other countries where only Muslim citizens have the obligation to fulfill the obligation of jihad to defend the country. Jizyah is also a kind of compulsory tax that is comparable to the obligation of Muslim citizens to pay zakat.

And this contract contains at least four obligations for non-Muslims; accept Islamic laws, pay jizyah every year, do not discredit Islam and do not do anything detrimental to Muslims. ${ }^{17}$ If in the future the non-Muslim dzimmi residents want to leave the dzimmah agreement, the Islamic government must fulfill it by removing them from Darul Islam and taking them to a place where they feel safe, outside Darul Islam. ${ }^{18}$ And if during the contract period, they committed treason (qitaal) for no justified reason (syubhah) then there was only one option, the death penalty. If it commits other violations that can damage the contents of the dzimmah agreement, the government has several choices of punishment; death penalty, being made a slave or asked for ransom. The government can also remove them from the Darul Islam area. This provision is excluded if they want to renew 'qad aldzimmah, then the government is obliged to comply. ${ }^{19}$

\footnotetext{
16 Ismail Zain Al-Yamani. Qurratul 'Ain. Rembang: Maktabah Al-Barokah. p. 199.

${ }^{17}$ Al-Hishni, Kifayatul Akhyar. (1994). Darul-Fikr, Lebanon, juz. 2, p. 175-176.

${ }^{18}$ Al-Haitami, Ibn Hajar. (2009). Tuhfatul Muhtaj in Hawasyi. Darul Fikr, Beirut-Lebanon, chapters 9 , p. 353.

${ }^{19}$ Zakariya AL-Anshari, Asnal Mathalib, Maktabah Syamilah, ch. 21, p. 228.
} 
Second, mu'āhad kafirs, namely non-Muslims residing in Darul harbi country, but their government is still in a period of peace agreement with the Darul Islam government. The peace agreement is called 'aqd al-hudnah. And the territory of their country is called dār al-'ahd. The agreement itself must be temporary. If Muslims are in a strong condition, then the agreement cannot be longer than 4 (four) months. And if it is in a weak state, it should not exceed 10 years. This agreement applies to the government of that country and all of its non-Muslim citizens. ${ }^{20}$ This agreement does not have the consequence of the obligation to pay jizyah for non-Muslims and the obligation of protection for the Darul Islam government and Muslims. This agreement is only in the form of a no war agreement. However, if they are in the area of Darul Islam then they will receive protection like the Kafir dzimmi. And included in this category of mu'ähad infidels, those who live in the Darul harbi region but make dzimmah agreements with the Darul Islam government. ${ }^{21}$

If the hudnah agreement has been canceled, the Darul Islam government may invade the area in the Darul harbi area. It's just that, if there are non-Muslim mu'āhad who are still in the Darul Islam area, then Muslims still cannot harm them. It is the responsibility of the Darul Islam government to escort these non-Muslims out of the Darul Islam area and take them to a place that is deemed safe or their place of origin. ${ }^{22}$

Third, the musta'man kafirs are non-Muslims who are actually harbi but they come to the Darul Islam area who get 'aqd al-amān or security guarantees, namely protection 'aqd al-amān whether from the government or from a Muslim despite having the lowest social status such as slaves, or Muslim citizens who are ungodly or ignorant.23 During their stay in the Darul Islam area, they have guaranteed protection rights from the Darul Islam government and all Muslim citizens both in life, property and honor. The agreement period cannot be more than 4 (four) months. According to other opinions, it should not exceed 1 (one) year. Unlike the aqd al-hudnah which can be canceled at any time, this 'aqd al-amān cannot be canceled by the Darul Islam government or Muslim citizens who provide guarantees, unless it is known that there is betrayal by the kafir musta'man concerned. ${ }^{24}$ This agreement is not followed by an obligation to pay jizyah as in 'aqd al-dzimmah. However, it is possible for the government to provide 'aqd alamān, to impose a kind of tax if it is deemed necessary, such as when they came to Darul Islam for trading purposes. ${ }^{25}$

And fourth, kafir harbi, namely non-Muslims who do not or refuse to do one of the 'aqd al-dzimmah,'aqd al-hudnah and 'aqd al-amān. Those whose territories were conquered by Muslims then rejected their 'aqd al-dzimmah to mean kafir harbi. As a consequence, they had to leave the area which had become Darul Islam. If they have done 'aqd al-dzimmah, they can change their status to kafir harbi if

\footnotetext{
${ }^{20}$ Al-Haitami, Op. Cit., p. 254-255.

21 Ibid. p. 257.

22Ibid. p. 358-359.

23Ibid. p. 309

${ }^{24}$ Ibid. p. 311-312.

25Zakariya AL-Anshari, Op. Cit., p. 199.
} 
they violate the contents of the agreement; namely refusing to pay jizyah or take any other action that destroys 'aqd al-dzimmah.

From the above explanation it is very clear, the division of kafir into four kinds is influenced by the context of the division of the world into Darul Islam and Darul Kufr as well as the context of territorial conquest (futuhät). The context of territorial conquest gave birth to the concept of kafir dzimmi and harbi. And the context of the division of the world into Darul Islam Kufr and Darul Kufr gave birth to a derivative concept in the form of the categories of kafir mu'āhad and kafir musta'man.

According to the results of the NU National Conference, the application of the concept of kafir dzimmi and harbi from the four categories of kafir above is not appropriate for non-Muslim citizens in Indonesia. Because Islam came to the archipelago not by conquest, let alone war. Islam came through peaceful preaching and discussion of the preachers with the indigenous people. Even the Indonesian State was founded jointly from the beginning by all elements of the nation consciously without making Islam the basis of the state. Despite the fact that the role of Muslims is the greatest.

From this fact, the State of Indonesia is closer to the context of the country of Medina at the beginning of the Prophet's arrival. Rasulullah brought the teachings of Islam in Medina peacefully, without conquest and without war. And by the Messenger of Allah, the Jewish community living in Medina was not subject to jizyah. Imam Shafi'i in the Book of Al-Umm affirms this historical fact:

"I do not know that historians have differing views on; In fact the Prophet when he arrived in Medina made an agreement with all the Jewish citizens without withdrawing the jizyah and in fact the verse of Allah [QS. Al-Maidah: 42] (which means) "... then if they come to you then decide the law between them or turn away from them ..." came down to the Jewish community who made the agreement; which they do not give jizyah and they do not accept to be treated (Islamic) law for them." 26

Dzimmi or ahlu al-dzimmah during the time of the Prophet as in the Medina Charter was different from the concept of post-futuhāt dzimmi. Before there was futuhāt, there was no obligation of jizyah and there was no obligation to follow Islamic law for Medina residents who embraced the Jewish religion, as explained by Imam Shafi'i above. Meanwhile, the obligation to pay jizyah was imposed after the war. This is clearly indicated by the following verse:

Fight against those who do not believe in Allah and the Last Day, those who do not forbid what Allah and the Messenger of Allah have forbidden, and do not have the true religion, (i.e. people) who have been given the book, until they pay jizyah obediently while they are in a submissive state. ${ }^{27}$

The above verse is the only verse that explains the obligation of jizyah. According to scholars' expert commentators, the verse came down to be the Prophet's guidance before leaving for war to face the Christian Roman soldiers in Tabuk. The departure of the Prophet and his troops was due to the plans of Roman troops to invade Medina. The verse provides a limitation or ghayyah that the war

\footnotetext{
${ }^{26}$ Al-Shafi'i, Muhammad bin Idris, Al-Umm, Maktabah Syamilah, juz IV, p. 210.

${ }^{27}$ QS. Al-Taubah, verse 29.
} 
order was valid until the Romans were willing to pay jizyah. Some scholars who are expert commentators say that the verse came down after the betrayal of the Bani Quraidhah and Bani Nadhir, two tribes of Medina residents who embraced the Jewish religion. They made efforts to fight the Prophet and the Messenger of Allah responded with war. ${ }^{28}$

So it can be concluded that the context of the jizyah obligation above is very different from the Indonesian context where the Islamic religion came brought by the preachers peacefully and without war. So the application of the four categories of kafir is not appropriate for non-Muslim citizens in the country of Indonesia. Also, it is not appropriate to be given the status of kafir harbi fì dzimmati al-ta'mīn as in the decision of Bahtsul Masail FMPP for the Residency of Kediri. These mentions are contradictory. Because harbi is not an infidel who is guaranteed safety. If harbi is a citizen of Darul Kufr who enters Darul Islam and has received security guarantees from the government or one of the citizens, then he gets a status bar, namely musta'man. If a harbi, his government performs'aqd al-hudnah, then he has got a new status, namely mu'ähad. These two categories are also not appropriate for non-Muslims in Indonesia. In addition, the status of kafir harbi fi dzimmati al-ta'min is not found in fiqh literature. Nor is it found in the marāji 'or fiqih literary references attached to the decision.

The four categories of kafir that exist in the books of fiqh do not change as fiqh laws in concept. It is still there. However, it cannot be applied in Indonesia because Indonesia as mahkūm 'alaih clearly and clearly is not the same as mahkūm 'alaih which the concept should be applied. And this search is including the above Tahqiìqul Manātmahall al-ḥukmi related to fakta history.

\section{Closing}

From this research it is concluded that Tahqiquul Manāt be a method of ijtihad in the application of fiqh law that has been compiled by Imam Madzhab into the problem at hand. In Tahqiqul Manāt, it must be ensured that the problems faced have the same legal illat. If no legal illat is found, then another law that also comes from the madzhab must be promulgated. With this Tahqiqul Manāt, bermadzhab will always be in line with the changing context of the times. As in determining the status of non-Muslims in Indonesia, some scholars are given the status of harbi fĩ dzimmati at-ta'mīn. If this fatwa or legal decision is carried out by Tahqīqul Manā in terms of the historical facts of non-Muslim people in Indonesia, it will not be suitable. Non-Muslims in Indonesia are more accurately referred to as non-Muslim citizens who cannot be called dzimmi or harbi with the consequences as second class citizens. Non-Muslims in Indonesia are citizens who have the same rights and obligations as Muslims, as well as the position of non-Muslims in Medina at the beginning of the Prophet's arrival.

\footnotetext{
${ }^{28} \mathrm{Abu}$ Hayyan Al-Anadalusi, Muhammad bin Yusuf, Tafsir Al-Bahrul Muhith, Maktabah Syamilah, ch. 6, p. 152.
} 


\section{References}

\section{Journal:}

[1] Sanusi, "Merajut Nalar Fiqih Kontekstual". Yudisia, Vol. 6, No. 2, (STAIN Kudus, 2015)

\section{Books:}

[1] Abu Hayyan Al-Anadalusi, Muhammad bin Yusuf, tt, Tafsir Al-Bahrul Muhith, Maktabah Syamilah

[2] Ahmad Nahrawi Abdussalam. (1988). Al-imām al-syafi'i fi madzhabaihi alqadìm wal jadìd

[3] Al-Ghazali, Abu Hamid Muhammad bin Muhammad. (2012). Al-muștașfa min 'ilm al-ușul, Muassasah Arrisalah, Cet.I, Al-Risālah, Beirut, Lebanon

[4] Asas Al-Qiyas. (1993). Al-Ubaikan, Riyadl, Saudi Arabia.

[5] Syifaaul-Ghalil. (1971). Al-Irsyad, Baghdad, Irak.

[6] Al-Haitami, Ibnu Hajar. (2009). Tuhfatul Muhtaj dalam Hawasyi. Darul Fikr, Beirut, Lebanon

[7] Al-Hishni, Taqiyuddin, Abu Bakr. (1994). Kifayatul Akhyar. Darul Fikr, Beirut, Lebanon

[8] Ibnu 'Asyur, Muḥammad Aț-Ṭahir. (1997). Tafsīr at-Tahrīr wat-Tanwīr, Dar Sahnun, Tunisia

[9] Ismail Zain Al-Yamani, tt, Qurratul 'Ain, Maktabah Al-Barokah, Rembang

[10] PBNU, Ahkamul Fuqaha; Solusi Problematika Aktual Hukum Islam; Keputusan Muktamar, Munas, dan Konbes Nahdlatul Ulama (1926-2004), 2010, Khalista dan LTNU Jawa Timur.

[11] PBNU, Materi Musyawarah Nasional Alim Ulama Nahdlatul Ulama 2019, Komisi Bahtsul Masail Ad-Diniyyah Al-Maudluiyyah.

[12] Sahal Mahfudh, in preface of Ahkamul Fuqaha; Hasil-hasil Keputusan Muktamar dan Permusyawaran lainnya (LTN PBNU, Cet. I, 2010).

[13] Al-Syafi'i, Muhammad bin Idris, tt, Al-Umm, Maktbah Syamilah

[14] Al-Syathibi, Ibrahim bin Musa Al-Andalusi. (2004). Al-Muwafaqat, Darul Kutub Al-Ilmiyyah, Beirut, Lebanon

[15] Al-Subki, Tajuddin, tt, Jam'ul Jawami', Darul Ilmi, Surabaya

[16] Al-Qarāfi. (2009). Al-Ihkam fii tamyiizil al-fatawa 'an al-ahkaamwa tsharrufat al-qaadli wa al-imaam, Cet. IV, Dār al-Basyāir al-Islamiyyah, Beirut, Lebanon

[17] Zakariyya al-Anshari, tt, Asnal Mathaalib, Maktabah Syamilah

\section{Internet:}

[1] http://www.gubuklentera.com/2016/11/status-non-muslim-diindonesia.html. Accessed on 14 February 2020, 21.00 WIB.

[2] http://www.gubuklentera.com/2016/11/konsep-jihad-dan-amar-marufnahi-munkar.html?m=1. Accessed on 14 February 2020, 21.10 WIB. 